\title{
Optimal duration of treatment with eculizumab in atypical hemolytic uremic syndrome (aHUS) - a question to be addressed in a scientific way
}

\author{
Gema Ariceta ${ }^{1}$ (D) \\ Received: 24 December 2018 / Accepted: 7 January 2019 / Published online: 28 January 2019 \\ (C) IPNA 2019
}

\section{Introduction}

Atypical hemolytic uremic syndrome (aHUS) is an ultrarare disease caused, in most cases, by dysregulation of the alternative complement $\left(\mathrm{C}^{\prime}\right)$ pathway at the surface of the vascular endothelium [1-3]. Uncontrolled $\mathrm{C}^{\prime}$ activation due to genetic abnormalities of several regulatory proteins, such as complement factor $\mathrm{H}(\mathrm{FH})$ [4-13] or auto-antibodies against $\mathrm{FH}$ synthesis $[14,15]$, lead to increased $\mathrm{C} 3$ convertase production and/or reduced degradation [16], which in turn result in excessive $\mathrm{C} 5$ activation, $\mathrm{C} 5 \mathrm{~b}-9$ formation (also named terminal complement complex (TCC)), and subsequently endothelial cell lysis $[17,18]$. Independent of the individual specific $\mathrm{C}^{\prime}$ anomaly, aHUS is a disease driven by a common pathogenic mechanism: C5 activation $[19,20]$.

Affected patients are vulnerable to $\mathrm{C}^{\prime}$ pathway stimulus and exhibit excessive $\mathrm{C} 3 \mathrm{~b}$ deposits on the surface of the endothelium membrane $[16,21]$. Incomplete penetrance $(\sim$ $50 \%$ ) of aHUS in mutation carriers is common. Concurrent environmental agents, commonly infections, or additional endothelial damaging factors, will further amplify $\mathrm{C}^{\prime}$ activation and trigger the disease due to impaired protection of microvasculature cells to $C^{\prime}$ injury [22]. The course of the disease is characterized by relapses separated by remission periods, both often preceded by external factors [1, 17-19]. It is generally accepted that individual predisposition to aHUS results from the combination of different inherited and environmental factors $[22,23]$.

Atypical hemolytic uremic syndrome is a disease characterized by thrombotic microangiopathy (TMA) which is defined by the concurrent triad of non-immune microangiopathic hemolytic anemia, thrombocytopenia, and vital organ

Gema Ariceta

gariceta@vhebron.net

1 Pediatric Nephrology, Hospital Universitari Vall d' Hebron, Universitat Autonoma de Barcelona, Barcelona, Spain damage, most frequently the kidney [1, 17-19]. The discovery that constitutive $\mathrm{C}^{\prime}$ alternative pathway dysregulation at the endothelial cell membrane surfaces plays a primary role in the pathogenic mechanism for most patients with aHUS provided a robust argument in favor of therapeutic complement blockade in those patients [20, 22-25]. Eculizumab, a humanized antibody which prevents $\mathrm{C} 5$ convertase activation that avoids TCC formation, and resulting endothelial damage, is the first in class complement blocker drug, effective in every specific $\mathrm{C}^{\prime}$ anomaly in patients with aHUS $[23,24]$. Eculizumab was approved by the FDA and EMA as a specific treatment for aHUS in 2011 [26, 27], after the success of four industrysponsored prospective non-randomized trials including 100 patients (78 adults and 22 children), which demonstrated hematologic remission with normalization of platelet count within 7-8 days; lactate dehydrogenase level (LDH) after 1454 days; and more importantly, a mean estimated glomerular filtration (eGFR) rate recovery of $64 \mathrm{~mL} / \mathrm{min} / 1.73 \mathrm{~m}^{2}$ in children and $30-35 \mathrm{~mL} / \mathrm{min} / 1.73 \mathrm{~m}^{2}$ in adults - a time-dependent response, with a more favorable outcome in those patients who started treatment during the first week of disease [28-31]. Since then, eculizumab has become the elective treatment of patients with aHUS [23-26] based on its remarkable positive effect on hematological remission, preservation renal function in native kidneys and to a lesser extent in kidney allografts, and recovery from extra-renal manifestations [29, $30,32]$, preventing disease recurrence after kidney transplantation (KTx) [33], even using selective living-related donor allografts in an individualized manner [32].

Therefore, treatment with eculizumab has changed the natural history of aHUS, substantially improving patient survival and outcome from the historic treatment with plasma exchange or infusion (PE/PI) [34, 35], a suboptimal therapy useful in the absence of eculizumab [23, 24, 34]. Prior to the availability of eculizumab, data from aHUS patient registries in different countries invariably described high rates of mortality, progression to end-stage kidney disease (ESKD), and disease recurrence risk in $60 \%$ of patients after KTx. 
Approximately, 29 and $56 \%$ of children and adults with aHUS, respectively, progressed to ESKD or died within 1 year of disease presentation [36, 37], and those with preserved renal function suffered more relapses later on-30\% within the first year and $20 \%$ of adults and $50 \%$ of children continued presenting relapses subsequently [37].

Recently, real-world data from The Global aHUS Registry demonstrated ESKD-free survival of 79 and $73 \%$ in pediatric patients with aHUS, and 69 and $51 \%$ in adult patients at 1 and 5 years, respectively, with similar outcome among different $\mathrm{C}^{\prime}$ abnormality statuses [38]. Further, case report descriptions have also supported the efficacy of eculizumab in recovery from systemic manifestations, such as in the central nervous system, ischemic cardiomyopathy, distal ischemia, necrotic skin lesions, and ophthalmologic involvement [22].

Since eculizumab is used as first-line therapy in children [23] and is also recommended early in the disease in adults after exclusion of other causes of TMA, mainly thrombotic thrombocytopenic purpura (TTP) [19, 22, 24], treated aHUS patients experience lack of relapses or disease activity in the long term [39]. Absence of disease activity has promoted large controversy regarding eculizumab dosing schedule and treatment duration.

\section{Challenges in aHUS diagnosis}

Overall, diagnosis of aHUS is based on patient clinical characteristics [1] due to the absence of a unique confirmatory test $[2,3]$. However, the phenotypic presentation of aHUS can be very heterogeneous due to variable disease severity and systemic involvement, as well as potential overlap with other manifestations caused by external triggers that may even mask the aHUS clinical picture [19]. Laborious differential diagnosis $[23,34]$ and disease rarity (incidence of $\sim 0.5$ per million per year) illustrate the challenge of establishing an accurate differential diagnosis [24], mainly in adults with associated comorbidities $[19,20,22]$.

At least $50-60 \%$ of aHUS patients have an underlying inherited and/or acquired $\mathrm{C}^{\prime}$ abnormality which explains the mechanism of the disease [17, 36, 37]. However, identification of a $\mathrm{C}^{\prime}$ gene pathogenic variant is not required for the diagnosis of aHUS [23, 39, 40]. Further, genetic analysis is complex, involves at least nine different genes $(C F H, C D 46$ $M C P, C F I, C 3, C F B, T H B D, C F H R 1, C F H R 5$, and DGKE), and should also include genotyping for the risk haplotypes (CFH-CFHR3 and MCPggaac) and detection of copy number variation, hybrid genes, and other complex genomic rearrangements in the CFH/CFHRs genomic region [19, 24]. Consequently, genetic diagnosis is usually not available at the acute phase of the disease and cannot support the diagnosis of aHUS [23] but may drive long-term management of the disease [22-24]. Further, grouped data from patient registries have demonstrated there is no difference in aHUS severity between patients with or without an identified $\mathrm{C}^{\prime}$ gene pathogenic variant. In addition, the response to eculizumab is similar in patients with or without identified mutations [38]. An exception to this rule is the detection of anti-FH antibodies which is a useful test that not only confirms the diagnosis but indicates a specific management including immunosuppression $[14,41]$.

Finally, recent efforts for terminology standardization of different entities causing TMA should provide clarification and facilitate the specific diagnosis and management of different aHUS subtypes, such as complement blockade in what is named "complement-mediated HUS" [42, 43].

\section{Eculizumab $^{\circledR}$ dosing schedule and treatment duration}

Eculizumab is administered by intravenous access [26, 27]. Approved prescription for aHUS in children and adults consists of an induction phase first, and later, a patient weightbased life-long maintenance dose at biweekly intervals, to target drug serum levels of $50-100 \mu \mathrm{g} / \mathrm{ml}$ [28-31]. However, this current standard is controversial, and the major question today is what the optimal duration of eculizumab treatment should be [24]. Patient burden associated with biweekly IV treatment is one of the arguments questioning eculizumab dosing, but the main controversies regard associated infection-risk and remarkably, cost.

\section{Infection-risk}

Administration of eculizumab prevents TCC formation, which represents the main immunity mechanism against Neisseria meningitis. Thus, the estimated risk of meningococcal infections in patients treated with eculizumab is $0.5 \%$ per year, a relative risk of 5000 compared to the general population, which is the same as for individuals with congenital complete deficiency in terminal $\mathrm{C}^{\prime}$ [23]. Vaccination against Neisseria serogroups A, C, W135, and Y and against serogroup B is mandatory before initiating eculizumab, but prescription of antibiotics during at least 2 weeks after vaccination avoids delaying treatment in emergency [26, 27]. The cumulative reporting rate of meningococcal infections in eculizumab-treated patients in the post-marketing setting was 0.33 per 100 patient-years (compared to 0.83 cases per 100 patient-years during clinical trials) [26]. Controversy remains regarding vaccination efficacy [24] and maintenance of antibiotic prophylaxis during the duration of eculizumab treatment $[19,23]$. In case of $C^{\prime}$ blockade interruption, antibiotics should be maintained for an additional 2-3 months [23, 24]. 


\section{Cost}

The annual cost of eculizumab treatment for a patient $>40 \mathrm{~kg}$ is $\sim € 500,000$ per year, which represents the most expensive treatment in the field of Pediatric Nephrology. Despite being a life-rescuing drug, eculizumab is unaffordable in many countries [44], or only available with specific restrictions [45]. The balance between pharmaceutical companies' economic incentives with societal budgetary constraints and the ethical imperative of timely access to expensive orphan drugs such as eculizumab is advocated [46].

\section{Complement activity monitoring and reduced eculizumab dose}

Some case reports have shown patients who remained in remission while receiving a reduced dose of eculizumab (often administered at longer intervals than approved label) or eculizumab cessation. Expert recommendations have opened the way for using lower eculizumab doses while preserving $\mathrm{C}^{\prime}$ blockade (measured by total complement activity or $\mathrm{CH} 50<$ $10 \%$ of normal, alternative pathway hemolytic activity or AH50 $<10 \%$ of normal, and eculizumab trough level 50 $100 \mathrm{mg} / \mathrm{ml}$ ) [24].

Following this concept, Gatault et al. developed a onecompartment model to predict pharmacokinetics and pharmacodynamics of eculizumab using the data of seven patients with aHUS and supported the extension of eculizumab infusion interval to 4 weeks in patients $<90 \mathrm{~kg}$ and even to 6 weeks in patients with body weight $<70 \mathrm{~kg}$ [47].

Since then, some reports analyzing $\mathrm{C}^{\prime}$ blockade in small cohorts of patients treated with prolonged intervals of eculizumab after a time on remission receiving the recommended dose have been published. Cugno et al. studied 18 aHUS patients (aged 2-40 years) treated with eculizumab in accordance with the standard scheme. Once they achieved remission, the time intervals between eculizumab infusions were progressively increased to 3 weeks and later 4 weeks, based on a patients' clinical condition and laboratory findings (haptoglobin, LDH, serum creatinine levels, platelet count, and $\mathrm{C}^{\prime}$ activity measured by Wieslab method- $-\mathrm{CH} 50, \mathrm{C} 3$ antigen and $\mathrm{C} 5$ activity levels). Patients were strictly monitored and weekly, a urine dipstick test was used to rule out hemoglobinuria. The duration of the study was 160 months. The authors observed that $\mathrm{C}^{\prime}$ functional activity was completely suppressed not only 1 and 2 weeks after the last eculizumab infusion but also after 3 weeks [48].

Volokhina et al. also analyzed 5 out of 8 aHUS patients receiving prolonged intervals of eculizumab. All patient samples were completely blocked for terminal $\mathrm{C}^{\prime}$ pathway activity for up to 4 weeks after eculizumab administration. Further, titration of serum complexes between eculizumab and C5 levels revealed an excess of the drug up to 4 weeks after infusion in the authors' opinion, but without providing real drug quantification [49]. A short time ago, the same group of authors, this time measuring drug levels in 11 aHUS patients treated with eculizumab given at infusion intervals of 4 5 weeks, described that $80 \%$ had eculizumab trough levels $>$ $50 \mu \mathrm{g} \mathrm{ml}$ and $\mathrm{C}^{\prime}$ fully blocked (as measured by $\mathrm{CH} 50<10 \%$ ) [50].

More recently, Ardissino et al. reported the outcome of prolonged intervals of eculizumab after 2.6 months of sustainable disease remission on the recommended drug dosing for 38 patients with aHUS (13 children). Twenty-two out of 38 patients received eculizumab every 4 weeks, and 16 out of 38 every 3 weeks, with a target of CH50 activity of $<30 \%$. After a cumulative median observation of 1208 months, none of the patients relapsed, and a median dose of eculizumab of $0.75 \mathrm{mg} / \mathrm{kg} /$ day was administered in comparison with the label dose of the drug that recommends $1.2 \mathrm{mg} / \mathrm{kg} / \mathrm{day}$ in a $70-\mathrm{kg}$ adult and $1.6 \mathrm{mg} / \mathrm{kg} /$ day in a $40-\mathrm{kg}$ child [51].

Those experiences are of great value and may help in moving from a standard and rigid eculizumab treatment scheme to a more personalized dosing approach. However, the key argument is the availability of monitoring patient $\mathrm{C}^{\prime}$ blockade in a timely manner. Interpretation of eculizumab levels is difficult since the assays differ from each other, and all detect both bound and unbound drug [24]. Functional assays of serum C ' activity (C3, C3d, C5, C5a, soluble C5b-C9, AP50) also provide conflicting or inconclusive results between different labs, and ex vivo endothelial cell assay-proposed as the gold-standard for aHUS activity monitoring - in practice is not available outside the research environment [21]. Further, we have limited understanding of the time course of a clinical episode of aHUS and whether disease activity persists or not [24]. Study cohorts sizes, potential center effects, limited patient follow-up, and disease pattern course characterized by remission and recurrent phases all justify caution and raise the question of generalization of those results from expert centers to general clinical practice. In addition, comparison between similar risk individuals is challenging, with mostly adult patients - who present with late onset of the disease after a robust environmental trigger - among those treated with reduced eculizumab dose, whose recurrence risk may differ from children affected by the disease from early life.

\section{Discontinuation of eculizumab and restrictive use}

There are no robust prospective controlled studies in patients with aHUS to define criteria for discontinuation of eculizumab therapy, but there are an increasing number of reports of patients who remained on remission after treatment cessation. A key question is whether patients with aHUS have alternative $\mathrm{C}$ ' pathway continuous hyperactivation and induced endothelial cell damage or not. Experts recommended that 
discontinuation of eculizumab could be considered on a caseby-case basis in patients after at least 6 to 12 months of treatment (or after 3 months in children with pathogenic $M C P$ variants) and at least 3 months of normalization (or stabilization of residual chronic kidney disease) of kidney function, excluding KTx recipients and children younger than 3 years of age $[23,24,32]$.

Some isolated case reports, and recently, larger cohort descriptions, have shown that interruption of eculizumab could be feasible in some patients. Ardissino et al. reported that in 10 aHUS patients who stopped eculizumab, 3 of them-all with $\mathrm{CFH}$ pathogenic variants - experienced a relapse within 6 weeks of discontinuation but completely recovered after immediately resuming treatment [52]. In a more recent publication from the same authors describing a total of 16 patients who discontinued eculizumab, 5/16 patients (31\%) also experienced a relapse, and previous renal function recovered after reintroducing eculizumab. Most relapses occurred a short time after treatment cessation. Study follow-up ranged from 0.4 to 40 months [53].

In a parallel approach, the Dutch group of Wijnsma et al. [54] described 20 patients (14 adults, 6 children) with aHUS, in whom eculizumab was tapered in all and stopped in 17 patients. aHUS recurrence occurred in 5 patients (with $C F H$ or $C F B$ pathogenic variants), and early detection and treatment restart prevented any clinical sequelae. In total, eculizumab was discontinued in 13 patients without aHUS recurrence, of whom 5 were event free for $>$ 1 year.

In agreement with previous studies, data from the noninterventional Global aHUS Registry (NCT01522183) demonstrated that among 1147 aHUS patients treated with eculizumab, those who remained on treatment had a lower TMA rate than patients who discontinued treatment (3.6 versus 10.7 per 100 patient-years, respectively) [55].

Overall, the available data indicate that eculizumab discontinuation may be reasonable in patients without detected $\mathrm{C}^{\prime}$ gene variants. In the largest retrospective series, none of the 17 patients with no rare variant detected relapsed, and the estimated relapse-risk in that sort of patient is $<10 \%$ [56]. Conversely, 8 of 11 patients (72\%) with $C F H$ variants and 4 of $8(50 \%)$ with $M C P$ variants relapsed after treatment cessation. In all case reports combined, the risk of relapse after eculizumab discontinuation was $60 \%, 37.5 \%$, and $43 \%$ in patients with $C F H, M C P$, and $C 3$ variants, respectively. In the majority of cases, fast restart of eculizumab achieved remission without additional kidney damage. No information regarding very infrequent variants is available [32]. The specific subtype of aHUS caused by auto-antibodies against FH $[14,15]$ represents the most appealing subtype for eculizumab interruption, but again "real life" experience has shown better outcome in those patients continuing treatment with eculizumab [41].
Nevertheless, there is a lack of data about the long-term impact of eculizumab discontinuation in the discussed published cohorts. A major criticism is that those studies could be biased, since eculizumab may be withdrawn in selected patients and not per protocol in all of them. The fact that in most centers extensive genetic analysis is not achievable in the short-term, as well as limited clinical experience, represents an additional challenge to following that approach.

A new strong statement in favor of a restrictive approach for eculizumab treatment in aHUS, based on the studies discussed above and our own experience [52-56], has been advocated recently [57]. Expert research on $\mathrm{C}^{\prime}$ and a skilled Dutch clinical group has published a restrictive therapeutic aHUS protocol based on patient age, $\mathrm{C}^{\prime}$ gene variant profile, and coordination by a national referent center, to provide distinct eculizumab treatment patterns in terms of duration, full or reduced dose, and complete or partial $\mathrm{C}^{\prime}$ activity blockade [57]. Unfortunately, the outcome of that approach is still unknown as a prospective observational national monitoring project (CUREiHUS, NTR5988) to guide eculizumab therapy in aHUS is ongoing.

Finally, the proposed restrictive approach in aHUS in adult transplant patients or in adult candidates for KTx [57] is highly questionable due to controversial results, limited recovery after eculizumab resumption, and lack of alignment with expert recommendations [22-24, 33]. New information from the Global aHUS Registry analyzing the outcome of $188 \mathrm{KTx}$ patients with at least 1 year of followup after their most recent transplant demonstrated significantly better 2 -year eGFR $\left(70.2 \mathrm{ml} / \mathrm{min} / 1.73 \mathrm{~m}^{2}\right)$ in the subgroup of patients receiving eculizumab beginning at the time of transplantation in comparison with the subgroup receiving eculizumab after KTx with a previous diagnosis of aHUS $\left(44.8 \mathrm{ml} / \mathrm{min} / 1.73 \mathrm{~m}^{2}\right)$ or the subgroup diagnosed with aHUS and treated after KTx $(24.2 \mathrm{ml} /$ $\min / 1.73 \mathrm{~m}^{2}$ ) [58].

\section{Conclusion}

Treatment with eculizumab has changed the natural history of complement-mediated HUS. Originally approved for long-life treatment, clinical experience from highly expert centers support moving from a fixed treatment schedule to a personalized dosing, at least in selected patients. Limitations in diseasemonitoring tools, and in genetic diagnosis in regular clinical practice, question the generalization of that approach. The balance between the ethical obligation to offer patients the best treatment, drug affordability, and patient risk requires a strict and rigorous prospective international research collaborative effort to provide proof and guidelines for aHUS future management. 


\section{Compliance with ethical standards}

Conflict of interest GA has received lecture and advisory honoraria from Alexion Pharmaceuticals and is a member of the Scientific Advisory Board of the Global aHUS Registry sponsored by Alexion Pharmaceuticals.

Publisher's note Springer Nature remains neutral with regard to jurisdictional claims in published maps and institutional affiliations.

\section{References}

1. Loirat C, Fremeaux-Bacchi V (2011) Atypical hemolytic uremic syndrome. Orphanet J Rare Dis 6:60

2. Loirat C, Saland J, Bitzan M (2012) Management of hemolytic uremic syndrome. Presse Med 41:e115-e135

3. Caprioli J, Noris M, Brioschi S, Pianetti G, Castelletti F, Bettinaglio P, Mele C, Bresin E, Cassis L, Gamba S, Porrati F, Bucchioni S, Monteferrante G, Fang CJ, Liszewski MK, Kavanagh D, Atkinson JP, Remuzzi G, International Registry of Recurrent and Familial HUS/TTP (2006) Genetics of HUS: the impact of MCP, CFH, and IF mutations on clinical presentation, response to treatment, and outcome. Blood 108:1267-1279

4. Caprioli J, Bettinaglio P, Zipfel PF, Amadei B, Daina E, Gamba S, Skerka C, Marziliano N, Remuzzi G, Noris M, Italian registry of familial and recurrent HUS/TTP (2001) The molecular basis of familial hemolytic uremic syndrome: mutation analysis of factor $\mathrm{H}$ gene reveals a hot spot in short consensus repeat 20. J Am Soc Nephrol 12:297-307

5. Pérez-Caballero D, González-Rubio C, Gallardo ME, Vera M, López-Trascasa M, Rodríguez de Córdoba S, Sánchez-Corral P (2001) Clustering of missense mutations in the C-terminal region of factor $\mathrm{H}$ in atypical hemolytic uremic syndrome. Am J Hum Genet 68:478-484

6. Richards A, Buddles MR, Donne RL, Kaplan BS, Kirk E, Venning MC, Tielemans CL, Goodship JA, Goodship TH (2001) Factor H mutations in hemolytic uremic syndrome cluster in exons 18-20, a domain important for host cell recognition. Am J Hum Genet 68: 485-490

7. Richards A, Kemp EJ, Liszewski MK, Goodship JA, Lampe AK, Decorte R, Müslümanoğlu MH, Kavukcu S, Filler G, Pirson Y, Wen LS, Atkinson JP, Goodship TH (2003) Mutations in human complement regulator, membrane cofactor protein (CD46), predispose to development of familial hemolytic uremic syndrome. Proc Natl Acad Sci U S A 100:12966-12971

8. Noris M, Brioschi S, Caprioli J, Todeschini M, Bresin E, Porrati F, Gamba S, Remuzzi G, International Registry of Recurrent and Familial HUS/TTP (2003) Familial haemolytic uraemic syndrome and an MCP mutation. Lancet 362:1542-1547

9. Fremeaux-Bacchi V, Dragon-Durey MA, Blouin J, Vigneau C, Kuypers D, Boudailliez B, Loirat C, Rondeau E, Fridman WH (2004) Complement factor I: a susceptibility gene for atypical haemolytic uraemic syndrome. J Med Genet 41:e84

10. Goicoechea de Jorge E, Harris CL, Esparza-Gordillo J, Carreras L, Arranz EA, Garrido CA, López-Trascasa M, Sánchez-Corral P, Morgan BP, Rodríguez de Córdoba S (2007) Gain-of-function mutations in complement factor $\mathrm{B}$ are associated with atypical hemolytic uremic syndrome. Proc Natl Acad Sci U S A 104:240-245

11. Fremeaux-Bacchi V, Miller EC, Liszewski MK, Strain L, Blouin J, Brown AL, Moghal N, Kaplan BS, Weiss RA, Lhotta K, Kapur G, Mattoo T, Nivet H, Wong W, Gie S, Hurault de Ligny B, Fischbach M, Gupta R, Hauhart R, Meunier V, Loirat C, Dragon-Durey MA, Fridman WH, Janssen BJ, Goodship TH, Atkinson JP (2008)
Mutations in complement $\mathrm{C} 3$ predispose to development of atypical hemolytic uremic syndrome. Blood 112:4948-4952

12. de Córdoba SR, de Jorge EG (2008) Translational mini-review series on complement factor $\mathrm{H}$ : genetics and disease associations of human complement factor H. Clin Exp Immunol 151:1-13

13. Delvaeye M, Noris M, De Vriese A, Esmon CT, Esmon NL, Ferrell G, Del-Favero J, Plaisance S, Claes B, Lambrechts D, Zoja C, Remuzzi G, Conway EM (2009) Thrombomodulin mutations in atypical hemolytic-uremic syndrome. N Engl J Med 361:345-357

14. Dragon-Durey M-A, Loirat C, Cloarec S, Macher MA, Blouin J, Nivet H, Weiss L, Fridman WH, Frémeaux-Bacchi V (2005) Antifactor $\mathrm{H}$ autoantibodies associated with atypical hemolytic uremic syndrome. J Am Soc Nephrol 16:555-563

15. Józsi M, Strobel S, Dahse HM, Liu WS, Hoyer PF, Oppermann M, Skerka C, Zipfel PF (2007) Anti factor H autoantibodies block Cterminal recognition function of factor $\mathrm{H}$ in hemolytic uremic syndrome. Blood 110:1516-1518

16. Roumenina LT, Jablonski M, Hue C, Blouin J, Dimitrov JD, Dragon-Durey MA, Cayla M, Fridman WH, Macher MA, Ribes D, Moulonguet L, Rostaing L, Satchell SC, Mathieson PW, SautesFridman C, Loirat C, Regnier CH, Halbwachs-Mecarelli L, Fremeaux-Bacchi V (2009) Hyperfunctional C3 convertase leads to complement deposition on endothelial cells and contributes to atypical hemolytic uremic syndrome. Blood 114:2837-2845

17. Noris M, Remuzzi G (2009) Atypical hemolytic uremic syndrome. N Engl J Med 361:1676-1687

18. Kavanagh D, Goodship TH, Richards A (2013) Atypical hemolytic uremic syndrome. Semin Nephrol 33:508-530

19. Campistol JM, Arias M, Ariceta G, Blasco M, Espinosa L, Espinosa M, Grinyó JM, Macía M, Mendizábal S, Praga M, Román E, Torra R, Valdés F, Vilalta R, Rodríguez de Córdoba S (2015) An update for atypical haemolytic uraemic syndrome: diagnosis and treatment. A consensus document. Nefrologia 35:421-447

20. Nester CM, Barbour T, de Cordoba SR, Dragon-Durey MA, Fremeaux-Bacchi V, Goodship TH, Kavanagh D, Noris M, Pickering M, Sanchez-Corral P, Skerka C, Zipfel P, Smith RJ (2015) Atypical aHUS: state of the art. Mol Immunol 67:31-42

21. Noris M, Galbusera M, Gastoldi S, Macor P, Banterla F, Bresin E, Tripodo C, Bettoni S, Donadelli R, Valoti E, Tedesco F, Amore A, Coppo R, Ruggenenti P, Gotti E, Remuzzi G (2014) Dynamics of complement activation in aHUS and how to monitor eculizumab therapy. Blood 124:1715-1726

22. Fakhouri F, Zuber J, Frémeaux-Bacchi V, Loirat C (2017) Haemolytic uraemic syndrome. Lancet 390:681-696

23. Loirat C, Fakhouri F, Ariceta G, Besbas N, Bitzan M, Bjerre A, Coppo R, Emma F, Johnson S, Karpman D, Landau D, Langman CB, Lapeyraque AL, Licht C, Nester C, Pecoraro C, Riedl M, van de Kar NC, Van de Walle J, Vivarelli M, Frémeaux-Bacchi V, HUS International (2016) An international consensus approach to the management of atypical hemolytic uremic syndrome in children. Pediatr Nephrol 31:15-39

24. Goodship TH, Cook HT, Fakhouri F, Fervenza FC, FrémeauxBacchi V, Kavanagh D, Nester CM, Noris M, Pickering MC, Rodríguez de Córdoba S, Roumenina LT, Sethi S, Smith RJ, Conference Participants (2017) Atypical hemolytic uremic syndrome and $\mathrm{C} 3$ glomerulopathy: conclusions from a "kidney disease: improving global outcomes" (KDIGO) controversies conference. Kidney Int 91:539-551

25. Gruppo RA, Rother RP (2009) Eculizumab for congenital atypical hemolytic-uremic syndrome. N Engl J Med 360:544-546

26. US Food and Drug Administration (2015) Soliris (eculizumab) [prescribing information]. Alexion Pharmaceuticals, Inc., Cheshire

27. European Medicines Agency. Soliris (eculizumab): EU summary of product characteristics http://www.emea.europa.eu/docs/en_GB/ document library/EPAR Product Information/human/000791/ WC500054208.pdf. Accessed 13 Jan 2019 
28. Legendre CM, Licht C, Muus P, Greenbaum LA, Babu S, Bedrosian C, Bingham C, Cohen DJ, Delmas Y, Douglas K, Eitner F, Feldkamp T, Fouque D, Furman RR, Gaber O, Herthelius M, Hourmant M, Karpman D, Lebranchu Y, Mariat C, Menne J, Moulin B, Nürnberger J, Ogawa M, Remuzzi G, Richard T, Sberro-Soussan R, Severino B, Sheerin NS, Trivelli A, Zimmerhackl LB, Goodship T, Loirat C (2013) Terminal complement inhibitor eculizumab in atypical hemolytic-uremic syndrome. N Engl J Med 368:2169-2181

29. Fakhouri F, Hourmant M, Campistol JM, Cataland SR, Espinosa M, Gaber AO, Menne J, Minetti EE, Provôt F, Rondeau E, Ruggenenti P, Weekers LE, Ogawa M, Bedrosian CL, Legendre CM (2016) Terminal complement inhibitor eculizumab in adult patients with atypical hemolytic uremic syndrome: a single-arm, open-label trial. Am J Kidney Dis 2016:84-93

30. Greenbaum LA, Fila M, Ardissino G, Al-Akash SI, Evans J, Henning P, Lieberman KV, Maringhini S, Pape L, Rees L, van de Kar NC, Vande Walle J, Ogawa M, Bedrosian CL, Licht C (2016) Eculizumab is a safe and effective treatment in pediatric patients with atypical hemolytic uremic syndrome. Kidney Int 89:701-711

31. Licht C, Greenbaum LA, Muus P, Babu S, Bedrosian CL, Cohen DJ, Delmas Y, Douglas K, Furman RR, Gaber OA, Goodship T, Herthelius M, Hourmant M, Legendre CM, Remuzzi G, Sheerin N, Trivelli A, Loirat C (2015) Efficacy and safety of eculizumab in atypical hemolytic uremic syndrome from 2-year extensions of phase 2 studies. Kidney Int 87:1061-1073

32. Fakhouri F, Loirat C (2018) Anticomplement treatment in atypical and typical hemolytic uremic syndrome. Semin Hematol 55:150158

33. Zuber J, Le Quintrec M, Krid S, Bertoye C, Gueutin V, Lahoche A, Heyne N, Ardissino G, Chatelet V, Noël LH, Hourmant M, Niaudet P, Frémeaux-Bacchi V, Rondeau E, Legendre C, Loirat C, French Study Group for Atypical HUS (2012) Eculizumab for atypical hemolytic uremic syndrome recurrence in renal transplantation. Am J Transplant 12:3337-3354

34. Ariceta G, Besbas N, Johnson S, Karpman D, Landau D, Licht C, Loirat C, Pecoraro C, Taylor CM, Van de Kar N, Vandewalle J, Zimmerhackl LB, European Paediatric Study Group for HUS (2009) Guideline for the investigation and initial therapy of diarrhea-negative hemolytic uremic syndrome. Pediatr Nephrol 24:687-696

35. Johnson S, Stojanovic J, Ariceta G, Bitzan M, Besbas N, Frieling M, Karpman D, Landau D, Langman C, Licht C, Pecoraro C, Riedl M, Siomou E, van de Kar N, Walle JV, Loirat C, Taylor CM (2014) An audit analysis of a guideline for the investigation and initial therapy of diarrhea negative (atypical) hemolytic uremic syndrome. Pediatr Nephrol 29:1967-1978

36. Noris M, Caprioli J, Bresin E, Mossali C, Pianetti G, Gamba S, Daina E, Fenili C, Castelletti F, Sorosina A, Piras R, Donadelli R, Maranta R, van der Meer I, Conway EM, Zipfel PF, Goodship TH, Remuzzi G (2010) Relative role of genetic complement abnormalities in sporadic and familial aHUS and their impact on clinical phenotype. Clin J Am Soc Nephrol 5:1844-1859

37. Fremeaux-Bacchi V, Fakhouri F, Garnier A, Bienaimé F, DragonDurey MA, Ngo S, Moulin B, Servais A, Provot F, Rostaing L, Burtey S, Niaudet P, Deschênes G, Lebranchu Y, Zuber J, Loirat C (2013) Genetics and outcome of atypical hemolytic uremic syndrome: a Nationwide French series comparing children and adults. Clin J Am Soc Nephrol 8:554-562

38. Schaefer F, Ardissino G, Ariceta G, Fakhouri F, Scully M, Isbel N, Lommelé Å, Kupelian V, Gasteyger C, Greenbaum LA, Johnson S, Ogawa M, Licht C, Vande Walle J, Frémeaux-Bacchi V, Global aHUS Registry (2018) Global aHUS registry. Clinical and genetic predictors of atypical hemolytic uremic syndrome phenotype and outcome. Kidney Int 94:408-418
39. Menne J, Delmas Y, Fakhouri F, Kincaid JF, Licht C, Minetti EE, Mix C, Provôt F, Rondeau E, Sheerin NS, Wang J, Weekers LE, Greenbaum LA (2018) Eculizumab prevents thrombotic microangiopathy in patients with atypical haemolytic uraemic syndrome in a long-term observational study. Clin Kidney J. https://doi.org/10. 1093/ckj/sfy035

40. Lemaire M, Frémeaux-Bacchi V, Schaefer F, Choi M, Tang WH, Le Quintrec M, Fakhouri F, Taque S, Nobili F, Martinez F, Ji W, Overton JD, Mane SM, Nürnberg G, Altmüller J, Thiele H, Morin D, Deschenes G, Baudouin V, Llanas B, Collard L, Majid MA, Simkova E, Nürnberg P, Rioux-Leclerc N, Moeckel GW, Gubler MC, Hwa J, Loirat C, Lifton RP (2013) Recessive mutations in DGKE cause atypical hemolytic-uremic syndrome. Nat Genet 45 : 531-536

41. Brocklebank V, Johnson S, Sheerin TP, Marks SD, Gilbert RD, Tyerman K, Kinoshita M, Awan A, Kaur A, Webb N, Hegde S, Finlay E, Fitzpatrick M, Walsh PR, Wong EKS, Booth C, Kerecuk L, Salama AD, Almond M, Inward C, Goodship TH, Sheerin NS, Marchbank KJ, Kavanagh D (2017) Factor H autoantibody is associated with atypical hemolytic uremic syndrome in children in the United Kingdom and Ireland. Kidney Int 92:1261-1271

42. Scully M, Cataland S, Coppo P, de la Rubia J, Friedman KD, Kremer Hovinga J, Lämmle B, Matsumoto M, Pavenski K, Sadler E, Sarode R, Wu H, International Working Group for Thrombotic Thrombocytopenic Purpura (2017) Consensus on the standardization of terminology in thrombotic thrombocytopenic purpura and related thrombotic microangiopathies. J Thromb Haemost 15:312-322

43. Kato H, Nangaku M, Okada H, Kagami S (2018) Controversies of the classification of TMA and the terminology of aHUS. Clin Exp Nephrol 22:979-980

44. Karpman D, Höglund P (2017) Orphan drug policies and use in pediatric nephrology. Pediatr Nephrol 32:1-6

45. NICE (National Institute for Health and Care Excellence) (2015) Eculizumab for treating atypical haemolytic uraemic syndrome NIfHaCE. https://www.nice.org.uk/guidance/hst1/resources/ eculizumab-fortreating-atypical-haemolytic-uraemic-syndromepdf. Accessed 28 Jan 2015

46. Rodriguez-Monguio R, Spargo T, Seoane-Vazquez E (2017) Ethical imperatives of timely access to orphan drugs: is possible to reconcile economic incentives and patients' health needs? Orphanet J Rare Dis 12:1-8

47. Gatault P, Brachet G, Ternant D, Degenne D, Récipon G, Barbet C, Gyan E, Gouilleux-Gruart V, Bordes C, Farrell A, Halimi JM, Watier H (2015) Therapeutic drug monitoring of eculizumab: rationale for an individualized dosing schedule. MAbs 7:1205-1211

48. Cugno M, Gualtierotti R, Possenti I, Testa S, Tel F, Griffini S, Grovetti E, Tedeschi S, Salardi S, Cresseri D, Messa P, Ardissino G (2014) Complement functional tests for monitoring eculizumab treatment in patients with atypical hemolytic uremic syndrome. J Thromb Haemost 12:1440-1448

49. Volokhina E, van de Kar N, Bergseth G, van der Velden TJ, Westra D, Wetzels JF, van den Heuvel LP, Mollnes TE (2015) Sensitive, reliable and easy-performed laboratory monitoring of eculizumab therapy in atypical hemolytic uremic syndrome. Clin Immunol 160: 237-243

50. Volokhina E, Wijnsma K, van der Molen R, Roeleveld N, van der Velden T, Goertz J, Sweep F, Brüggemann RJ, Wetzels J, van de Kar N, van den Heuvel L (2017) Eculizumab dosing regimen in atypical HUS: possibilities for individualized treatment. Clin Pharmacol Ther 102:671-678

51. Ardissino G, Tel F, Sgarbanti M, Cresseri D, Giussani A, Griffini S, Grovetto E, Possenti I, Perrone M, Testa S, Paglialonga F, Messa P, Cugno M (2018) Complement functional tests for monitoring eculizumab treatment in patients with atypical hemolytic uremic syndrome: an update. Pediatr Nephrol 33:457-461 
52. Ardissino G, Testa S, Possenti I, Tel F, Paglialonga F, Salardi S, Tedeschi S, Belingheri M, Cugno M (2014) Discontinuation of eculizumab maintenance treatment for atypical hemolytic uremic syndrome: a report of 10 cases. Am J Kidney Dis 64:633-637

53. Ardissino G, Possenti I, Tel F, Testa S, Salardi S, Ladisa V (2015) Discontinuation of eculizumab treatment in atypical hemolytic uremic syndrome: an update. Am J Kidney Dis 66:172-173

54. Wijnsma KL, Duineveld C, Volokhina E, van den Heuvel LP, van de Kar N, Wetzels J (2018) Safety and effectiveness of restrictive eculizumab treatment in atypical haemolytic uremic syndrome. Nephrol Dial Transplant 33:635-645

55. Ariceta G, Ardissino G, Sartz L, Fakhouri F, Gasteyger C, AlDakkak I (2018) Thrombotic microangiopathy frequency in patients with atypical HUS: discontinuing vs remaining on eculizumab treatment. Kidney Week, ASN J Am Soc Nephrol 29: 44 (abstract)
56. Fakhouri F, Fila M, Provôt F, Delmas Y, Barbet C, Châtelet V, Rafat C, Cailliez M, Hogan J, Servais A, Karras A, Makdassi R, Louillet F, Coindre JP, Rondeau E, Loirat C, Frémeaux-Bacchi V (2017) Pathogenic variants in complement genes and risk of atypical hemolytic uremic syndrome relapse after eculizumab discontinuation. Clin J Am Soc Nephrol 12:50-59

57. Wijnsma KL, Duineveld C, Wetzels JFM, van de Kar NCAJ (2018) Eculizumab in atypical hemolytic uremic syndrome: strategies toward restrictive use. Pediatr Nephrol. https://doi.org/10.1007/ s00467-018-4091-3

58. Siedlecki AM, Isbel N, Van de Walle J, Eggleston JJ, Cohen DJ, Global aHUS Registry (2018) Eculizumab use for kidney transplantation in patients with a diagnosis of atypical hemolytic uremic syndrome. Kidney Int Rep. https://doi.org/10.1016/j.ekir.2018.11. 010 